\title{
The Short and Long-Run Performance of Sharia-Compliant Initial Public Offerings (IPOs) in the Emerging Market: Evidence from the Saudi Arabia Share Market
}

\author{
Kamilah Kamaludin ${ }^{1, *}$ and Nadisah Zakaria $^{2}$ \\ ${ }^{1}$ Department of Finance, University Malaya-Wales, Malaysia \\ ${ }^{2}$ Finance Department, Prince Sultan University, Saudi Arabia
}

\begin{abstract}
This study examines the short- and long-run share performance of 40 Sharia-compliant IPO companies listed on the Saudi Arabia Stock Exchange (Tadawul) from $1^{\text {st }}$ January 2000 to $31^{\text {st }}$ August 2017 . This study employs both market-adjusted initial returns and buy-and-hold abnormal return to measure the share performance of IPOs. First, the analysis shows that Sharia-compliant IPOs are underpricing with abnormal initial returns of $79.23 \%$. Second, the results suggest that investors could earn positive and significant market-adjusted BHAR of $14.67 \%$ if they held IPO shares over the eighteen-month period following the listing date when EWI is used as a market benchmark. This study also finds that IPO companies outperformed the VWI although the results are insignificant. The findings on the long-run overperformance contribute to the IPO literature on long-run performance of Sharia-compliant IPOs. The present study would benefit foreign investors and market regulators who are trying to understand the market behaviour in an emerging market.
\end{abstract}

Keywords: Initial public offerings (IPOs), short- and long-run performance, Sharia-compliant investments, Kingdom of Saudi Arabia, buy-and-hold abnormal return (BHAR).

\section{INTRODUCTION}

The purpose of this study is to examine the shortand long-run financial performance of initial public offerings (IPO) of Sharia-compliant companies in Saudi Arabia for the period between 2000 and 2017. Many studies have examined the short- and long-run performance of IPO companies around the globe with mixed and inconclusive findings, at best. While there is almost a consensus that IPO initial return results in underpricing, the amount of average initial return varies tremendously from country to country. Similarly, mixed findings have been documented for long-run IPO performance, with on the one hand, findings of underperformance reported in the developed countries, like the US and UK (Espenlaub, Gregory, \& Tonks, 2000; Gompers \& Lerner, 2003; T. Loughran \& Ritter, 1995); Ritter (1991); and, on the other hand, evidences of overperformance in the developing countries like Malaysia, Singapore and Turkey (Ahmad-Zaluki, Campbell, \& Goodacre, 2007; Banu Durukan, 2002; P. Lee, S. Taylor, \& T. Walter, 1996b). Such mixed outcomes are controversial, as it clearly disproves the efficient market hypothesis that has been fundamental to market studies in finance.

Intrigued by where Saudi Arabia, an emerging economy, may be positioned on this continuum, this

*Address correspondence to this author at the Department of Finance, University Malaya-Wales, Malaysia; Tel: +966 11 4948102; Fax: +966 11 4548317; E-mail: nadisah@iumw.edu.my study examines and measures the short- and long-run performance of Sharia-compliant IPO companies. Several studies have been conducted for the Saudi market (see F. Alqahtani \& Boulanouar, 2017; Boulanouar \& Alqahtani, 2016; Mayes \& Alqahtani, 2015) and this research intends to update and enrich the literature on this matter. To this end, the authors believe that this work is comprehensive examining both the short- and long-run performances of Shariacompliant IPOs. The concept of Sharia-compliant investment has taken off from four decades ago but is only recently receiving coverage from the academic and business community. A small but steady growth in the literature is found in understanding the rationale, mechanism and performance of Sharia-compliant companies, particularly, in Malaysia and Indonesia but appears significantly limited in terms of quantity, quality and rigour.

Since the heart of Sharia law is in Saudi Arabia, the present study exploits this opportunity to investigate the IPO performance of Sharia-compliant companies. While an earlier study by Mayes and Alqahtani (2015) has explored a similar issue, their sample data between 2004 to 2010, is arguably concentrated in the period of economic boom; prior to the onset of financial crisis of 2008. Notably, this study attempts to provide sample of IPO activities and performance encompassing much longer period between 2004 to 2017 .

The increasing attractiveness in studying the emerging markets like Saudi Arabia and other Gulf 
Cooperation Council (GCC) countries was due to the fact that these countries are becoming important players among the global economies (Ahmed S. Alanazi, Liu, \& Forster, 2011). Earlier, the GCC had a rather closed policy to foreign investment, but have lifted this restriction and have started to welcome foreign investors from outside the region. From $1^{\text {st }}$ June 2015, the Capital Market Authority (CMA) of Saudi Arabia has allowed foreign financial institutions to buy and sell shares in companies listed on the Saudi Stock Exchange (Tadawul) as an effort to extend its market participants. Previously, international investors only had limited access to the Tadawul through instruments such as swaps and they only owned $7.74 \%$ of the Saudi Arabian share market's value (Bloomberg, 2016).

The present study documents several findings. First, the results report underpricing of IPO shares on the Saudi share market with a considerably high abnormal initial return of $79.23 \%$, significant at $5 \%$ level. Second, the present study finds overperformance of IPO shares in the long-run where the marketadjusted buy and hold abnormal return (BHAR) outperformed both market indices; (a) positive and significant when benchmarked against equal weight index (EWI); and (b) positive but not significant when benchmarked against VWI (value weight index). To some extent, this study is consistent with earlier findings by Mayes and Alqahtani (2015) about the underpricing phenomenon in the Saudi market. Nonetheless, the magnitude of underpricing in the present study is substantially lower, at almost one-half the amount found by Mayes and Alqahtani (2015). And as for the long-run performance, the Sharia-compliant IPO companies overperformed the market index as expected from an emerging market that does not necessarily operate in complete symmetrical information and efficient market condition (Mayes \& Alqahtani, 2015).

Understanding the IPO performance of an emerging market like Saudi Arabia would greatly benefit future investors in this region. While investors can expect high initial returns from IPO companies (Ritter, 1991), the findings of this research indicate that sustaining the investment on a longer horizon may be advantageous after all. The results of this work are also important to regulators and policymakers alike. Understanding that the capital market is not entirely efficient, policymakers should take necessary measures to improve this condition and enhance its competitiveness to parallel the capital markets in the developed countries.
The paper is organized as follows: Section II discusses the existing literature on short and long-run IPO performance. Section III presents our data and methodology. Section IV reports and discusses the findings of this research, and the final section concludes and provide recommendations for future research.

\section{LITERATURE REVIEW}

\subsection{Underpricing of Short-Run IPOs}

Following any IPOs, positive initial returns are considered as underpricing where 'money is being left on the table' (Tully, 1999) by the IPO companies. Underpricing is indicated when the closing market price is greater than the share listing price on its first day of trading. Some authors regard the underpricing phenomenon as an 'anomaly' as it contradicts the efficient market hypothesis arguments. Many theories have been proposed to explain IPO underpricing such as IPO timing during a bullish market, market volatility, 'ex-ante uncertainty' (Ritter, 1984), 'oversubscription' of IPOs (Rock, 1986) and the 'signalling approach'1 (Allen \& Faulhaber, 1989). Some authors believe that underpricing of IPOs is somewhat justified as the company is compensating the investors for additional risk from subscribing to newly listed shares companies.

One of the most comprehensive literatures that documented evidences for underpricing and continues to update them from time to time is the study by $\mathrm{T}$. Loughran, Ritter, and Rydqvist (1994), which was first published in 1994. In their latest update, in 2015, they managed to provide a list of initial returns for 52 countries from the developed and developing economies. There is an evident demarcation between the initial returns of the developed and developing countries. The developed countries report much lower initial returns, for example, Canada 6.5\%, France $10.5 \%$, Italy, $15.2 \%$, US $16.9 \%$ and UK, $16 \%$. As for the developing countries, T. Loughran et al. (1994) indicate a much higher initial return, for example, Morrocco 33.3\%, China $118.4 \%$, Malaysia $56.2 \%$, Korea $58.8 \%$, Taiwan $38.1 \%$ and Thailand $35.1 \%$.

Notably, from T. Loughran et al. (1994)'s study, Saudi Arabia is reported to have an average initial return of $239.8 \%$, which is the highest of the 52

\footnotetext{
${ }^{1}$ The signalling approach suggests that IPO firms tend to lower their initial public offerings to signal the quality of their firm to investors and later increase price for other subsequent seasoned issues.
} 
countries studied. The said initial return is calculated based on the following two studies namely, Ahmed S. Alanazi et al. (2011) and Faisal Alqahtani (2011) for a total of 80 IPOs in the period of 2003 to 2011. A more recent study in Saudi Arabia was conducted by Mayes and Alqahtani (2015) for 72 IPO companies between 2004 and September 2010. Mayes and Alqahtani (2015) also found a substantial level of underpricing at $267.14 \%$ initial return, even after adjusting for market movements. Both findings corroborate an earlier study by Al-Hassan, Delgado, and Omran (2010) who also reported substantial IPO underpricing in the GCC countries, reporting an average initial return of $290 \%$ after adjusting for market size. Al-Hassan et al. (2010) examine the IPO performance of six GCC countries Saudi Arabia, UAE, Bahrain, Oman, Qatar and Kuwait, with a total of 47 IPOs in the period between 2001 and 2006. Mayes and Alqahtani (2015) attributed the high level of underpricing to the bull market condition of the start-up offerings they were studying.

Mayes and Alqahtani (2015) went on to compare the level of underpricing between Sharia and nonSharia-compliant companies in KSA and found that the levels of underpricing are significantly reduced in Sharia-compliant companies. For example, their findings indicate that the adjusted initial return for nonSharia compliant companies is $400 \%$, whereas the Sharia-compliant companies is less than half at $160 \%$. They attributed such a substantial difference to the cost of compliance to Sharia regulations that alters the level of underpricing significantly. Despite the Shariacompliant companies reducing the level of underpricing, it still remained one of the highest underpricing levels reported for any country. Mayes and Alqahtani (2015) argued that the persistent underpricing results from the structural imperfections of Saudi financial markets and provide some recommendations to policy makers to reduce the monopsony powers of underwriters.

Another recent study in Saudi Arabia also examined IPO underpricing but focuses only on Sharia-compliant companies in the insurance industry. Boulanouar and Alqahtani (2016) examined 33 insurance companies in the period of 2007 to 2013 to find the level of underpricing in this sector. Consistent with Mayes and Alqahtani (2015) they reported a substantial level of underpricing with average initial returns of $455 \%$, the highest in the world. Like Mayes and Alqahtani (2015), they also attributed this substantial amount of underpricing to the monopsony power of the insurance underwriters, which are few in number in the industry.
Interestingly, contrary to (Mayes \& Alqahtani, 2015) they do not find that Sharia-compliant IPO insurance companies have a reduced level of underpricing. Similar findings have been found by other studies on Sharia-compliant companies in Malaysia. In Malaysia, for example, Abdul Rahim and Yong (2010) do not find any significant differences in terms of average initial returns between Sharia and non-Sharia-compliant IPO companies, which clearly indicates that status does not alter the patterns of initial returns of IPOs in Malaysia significantly.

\subsection{Long-Run Performance}

Short run IPO performance studies are persistently looking for the presence and causes of abnormal return or underpricing, but on a longer horizon, the literature notes that the abnormal return dissipates and investors are faced with underperformance instead. Once again, investors and researchers alike are faced with another anomaly, a puzzle to solve. Motivated by Ritter (1991) seminal paper on the long-run performance of IPOs, finance researchers world-wide are trying to identify and subsequently understand the causes behind this underperformance. In addition, the performance in the longer term is even more difficult to predict, as has been illustrated by some of the literature reviewed below. Clearly, there appears a delineation between the long-run performance of IPOs in developed and developing countries.

Many studies have examined US IPOs, with clear findings of underperformance regardless of the methods and benchmarks used (T. Loughran, 1993; T. Loughran \& Ritter, 1995; Ritter, 1991). Notably, T. Loughran and Ritter (1995)'s paper is the most comprehensive, sampling 4,753 IPO companies in the period spanning 20 years between 1970 and 1990 and applying both the event-time and calendar-time approaches in their method. They found over a period of 5 years, investors received average returns of only $5 \%$ per year from IPOs compared to $12 \%$ per year if the investment is directed at non-IPOs firms, hence, a clear evidence of underperformance in the long-run period.

In the UK, Espenlaub et al. (2000), Khurshed, Mudambi, and Goergen (1999), and Levis (1993) also reported findings of underperformance over the long run for IPO companies. In the UK, Espenlaub et al. (2000), used five benchmarks to measure performance, and interestingly irrespective of the measures used, found substantial negative returns post 
three years of listing, but over a longer period, i.e. five years, less evidence of underperformance was found. Other than the US and the UK, other developed countries also reported some level of underperformance in the long run. For example, $\mathrm{P}$. Lee, S. Taylor, and T. Walter (1996a), found underperformance over the long run in the Australian market for 266 IPO companies between the periods of 1976 to 1989. As for the European countries, Keloharju (1993) and Álvarez and González (2005) of Finland and Spain, respectively, also found significant findings of IPO underperformance over the long run. Stehle, Ehrhardt, and Przyborowsky (2000), studying the longrun performance of IPOs in Germany also found underperformance, but the results appear not significant.

Directing our attention to the East, the authors found that Malaysian and Singaporean IPOs defied the underperformance findings reported in the developed countries. Instead, Ahmad-Zaluki et al. (2007) found significant overperformance of IPO companies in the Malaysian market. Using a large sample data of more than 450 companies, long-run IPO performance is measured three years post-listing using the event-time and calendar-time approaches. Similarly, Lee et al. (1996b), also found that Singaporean IPO companies overperformed in the long run, although, their results were not significant. Banu Durukan (2002) in his study on Turkish IPOs also observed a similar pattern of overperformance, but the results were not significant.

Ahmad-Zaluki et al. (2007) study on the Malaysian market is particularly noted here, for its closeness in structure to the Saudi market in terms of the availability of Sharia investments, although their study did not focus on Sharia-compliant companies. Malaysia is highly acknowledged for the supply of Sharia-compliant equity investments (Mayes \& Alqahtani, 2015) and as such the overperformance of IPO companies in Malaysia may indirectly contribute to the overperformance of Sharia-compliant IPO companies, considering that $75 \%$ of companies in Malaysia are Sharia-compliant (Malaysia, 2017).

Closer to home, in Saudi Arabia, among the early attempts at formal analysis of IPO performance, Ahmed S. Alanazi et al. (2011) compared the pre- and post IPO financial performance of 16 companies that went public between 2003 and 2009. Using two accounting measures, namely, the return on assets (ROA) and return on sales (ROS), their analysis suggests that both financial measures fell significantly after the IPO. In the period of three years, the median average of ROA and ROS are found to be 30 percent and 12 percent, respectively, lower than the average three years before. The study, while noting their contribution to the Saudi market, is very small in size and does not benchmark against market performance. A more recent study on long-run IPO performance in Saudi Arabia was carried out by F. Alqahtani and Boulanouar (2017) analysing a sample of 72 IPOs between the period of 2004 and September 2010. They divided their sample into Sharia and non-Shariacompliant IPOs and, based on one-year market performance, reject the notion of underperformance in the Saudi market. They further suggested that Shariacompliant companies enjoyed superior non-negative returns compared to non-Sharia companies. Arguably, F. Alqahtani and Boulanouar (2017)'s characterization of long run is somewhat limited here. A window of performance of merely one year cannot be entirely considered as long run. In addition, their study is rather dated as their latest IPOs happened in 2010, almost seven years ago and many changes to the market have happened since. For one, the Saudi capital market has allowed foreign investments, which may alter the behaviour of market participants.

\section{METHODOLOGY}

\subsection{Sample Selection and Data}

This study investigates the short- and long-run share performance of Sharia-compliant IPO companies listed on the Saudi Arabia Stock Exchange (Tadawul) from $1^{\text {st }}$ January 2000 to $31^{\text {st }}$ August 2017. Shariacompliant companies consist of companies that receive a compliance status from the Sharia awarding body. In Saudi Arabia, there are several awarding bodies for Sharia companies but the most widely known is the Sharia Board of Al Rajhi Capital that has been used in earlier studies (see Boulanouar \& Alqahtani, 2016; Mayes \& Alqahtani, 2015). While it is not within the scope of the present study to compare the Sharia screening process of these different awarding bodies, for a quick review, Al Rajhi Capital provides the most comprehensive list as compared to other awarding bodies with sufficient explanation in English. According to Al Rajhi Capital's Sharia guidelines, for the shares to qualify as Sharia investments, the company's objectives, activities and controls must be within Islamic permissible parameters. This means, companies in any ways associated 'with illicit objectives and activities, including trading in wine, tobacco, pork, gambling, interest bearing banking activities, 
companies with insolent activities or films, funds dealing in interest-bearing bonds, and companies specialized in debt handlings and dealings are not permissible according to Sharia law and will not be granted Sharia compliance status' (Al-Rajhi Capital, 2017). As of Quarter 2, 2017, Al Rajhi Capital awarded 146 companies from a total of 178 companies listed on the Tadawul as Sharia-compliant investments.

Although our present work is motivated to analyse the long-run share market performance, the marketadjusted initial returns were also examined to provide evidence on whether IPO activity on the Saudi Arabian stock market is underpricing. The initial identities of 45 Sharia-compliant IPO companies were obtained from Bloomberg Professional Services, one of the primary and authoritative financial information providers. To be included in the final sample, Sharia-compliant IPO companies had to satisfy the following criteria: (1) an offer price of at least Saudi Arabia Riyal, SAR10; (2) an offering involving common stock only; (3) Shariacompliant companies are listed on the Tadawul; (4) an investment bank is responsible for the listing of IPOs; (5) the exclusion of withdrawn or pending IPOs; (6) the availability of monthly returns data from Bloomberg Professional Services for up to three years following the listing date; (7) the listing of IPOs did not result from a takeover or merger, or from an introduction and major restructuring scheme; (8) the exclusion of companies from Financial and Real Estate Investment Trust (REIT) Fund industry sectors. The number of Sharia-compliant IPO companies included in the final sample varies according to the type of analysis undertaken and the time windows under consideration. Notably, this study (a) incorporates 40 Shariacompliant IPO companies to investigate whether IPOs on the Saudi Arabian stock market were underpricing over the period $1^{\text {st }}$ January 2000 to $31^{\text {st }}$ August 2017; (b) includes 36 companies in the final sample to examine the one-to-three year post IPOs performance. To analyse the post IPOs performance, this study required 36 monthly returns data for the Shariacompliant IPO companies from January 2000 to December 2014; indicating that the period used in the present research is from 2000 through 2017.

To compute the raw initial returns, the closing share price data on the first day of listing and the offer price for each IPO were collected from Bloomberg Professional Services. Similarly, the market returns on the listing date, using the Tadawul All-Share Index (TASI) level as a proxy, were observed and subtracted from the IPOs' raw initial returns to compute the market-adjusted initial returns.
To compute the 36 monthly buy-and-hold returns for the Sharia-compliant IPO companies, the monthly closing prices for each IPO were gathered from Bloomberg Professional Services. The monthly buyand-hold returns for each IPO company were then compared with the monthly buy-and-hold market returns to derive the market-adjusted abnormal returns following the listing of Sharia-compliant IPO companies.

\subsection{Methods}

To evaluate the short- and long-run share performance of Sharia-compliant IPO companies, the present study employs standard event study methodology, namely the event time approach. Following Ritter (1991), this study computes the abnormal returns for the Sharia-compliant IPO companies as follows: (1) the initial returns and (2) the long-run post performance returns. This study defines initial returns as the returns earned by investors from purchasing the shares on the offering date, as disclosed in the prospectus, to the end of the first day of trading. The long-run post performance returns are defined as the returns earned by investors if the shares are purchased at the closing market price on the day of listing and held for36 months, excluding the initial return period. Using a similar approach to Ritter (1991), the initial return is defined to be month 0 , and the aftermarket period includes the subsequent 36 event months; for example, one-month period following the listing date of Sharia-compliant IPO companies.

\subsection{Initial Return: Market-Adjusted Initial Return}

There is a broad consensus in the literature suggesting that the underpricing phenomenon is not only found in the developed countries such as in the US and the UK, but also in the developing countries, for example Malaysia, Hong Kong and Singapore. Hence, it is of importance for this study to investigate whether the underpricing phenomenon occurs in an emerging market, in particular Saudi Arabia.

The raw initial return for each IPO is calculated as:

$R_{i t}=\frac{P_{i t}-S_{i o}}{S_{i o}}$

Where:

$R_{i t}=$ the initial return of company l's share;

$P_{i t}=$ the closing price on the first day of listing; 
$S_{i o}=$ the subscription price on the offering date

The market-adjusted initial return (MAIR) is calculated as:

$M A I R=R_{i t}-R_{m t}$

Where

$R_{m t}=$ the return on the market portfolio, proxy by the Tadawul All-Shares Index (TASI)

$$
R_{m t}=\left(I_{t}-I_{o}\right)-I_{o}
$$

Where:

$I_{t}$ and $I_{o}=$ the corresponding index levels

Note that, both $R_{i t}$ and $R_{m t}$ do not account for dividends as no dividend payments occurred in the short-run period.

To test whether the mean market-adjusted initial returns equal to zero, the authors compute the associated t-statistic as follows:

$t=(\overline{M A I R} \times \sqrt{n}) / s d$

$s d=$ the standard deviation of $\overline{M A I R}$ across the companies;

$n=$ the number of Sharia Compliant IPO companies in the sample.

\subsection{Long-Run Return: Buy-and-Hold Abnormal Return}

In spite of Lyon, Barber, and Tsai (1999) reminding us regarding the use of buy-and-hold abnormal returns (BHAR), extensive literature supports the use of the BHAR method as it tackles the effect of compounding better than the cumulative abnormal return (CAR) (Barber \& Lyon, 1997; Ritter, 1991). Fama (1998) affirmed that compounding short-term returns to obtain long-term BHAR better captures long-term investor experience. In fact, using solely the average abnormal returns used in the CAR approach does not precisely measure returns to investors over the long-run period. Gompers and Lerner (2003) also emphasize that the CAR method tends to misrepresent performance when returns are highly volatile. In modern event studies, the most comprehensive accepted methodology is the BHAR approach. For that reason, this study adopts this method to evaluate the share return performance of Sharia-compliant IPO companies over the long-run period. Ritter (1991) confirmed that in minimizing the problem related to measuring portfolios, benchmarking those portfolios is vital. Hence, this study applies two market indices: Equal-Weight Index (EWI) and Value Weight Index (VWI).

EWI gives the same weight or importance to each share listed on the Saudi Arabian stock market (Tadawul). Consistently, this approach gives the smallest companies equal weight to that of the largest companies. VWI provides each share listed on the Tadawul a weight according to the total market value of their outstanding shares. VWI represents the weights of individual shares proportionate to their market capitalization. Both EWI and VWI allow researchers to analyse the sensitivity of the results to the choice of the markets (Xiao and Arnold, 2008). As at $31^{\text {st }}$ August 2017, there are 187 companies listed on the Tadawul. To develop EWI and VWI indices, the share price data for each company traded on the Saudi Arabian Stock Exchange (Tadawul) was collected from Bloomberg Professional Services.

The market returns for the Saudi Arabian All-Shares Equal Weight Index (SAS-EWI) and Saudi Arabian AllShares Value Weight Index (SAS-VWI) of $n$ stock on event day $t$ are calculated as follows:

$R_{m t}=\sum_{j=1}^{n j} W_{j t} R_{j t}$

Where, $R_{m t}$ is the daily market returns in period $t$, $W_{j t}$ is the weight given, $1 / N_{t}$ is used to calculate equal-weighted market returns (as in SAS-EWI) and $M V_{t}$

$\sum M V_{t}$ is used to compute value-weighted market returns (as in SAS-VWI). $M V_{t}$ is the market capitalization of individual companies in period $t$.

The three-year holding period return is evaluated by computing the compounded monthly buy-and-hold return for Sharia Compliance IPO companies, for time as follows:

$$
B H R_{j T}=\left[\prod_{t=1}^{T}\left(1+r_{j t}\right)\right]-1
$$

Where, $r_{j t}$ is the actual monthly return on the share $j$ in event period $t$. $T$ is designated as the number of months in event period $t$. The condition measures the total return from a buy-and-hold strategy where a share is purchased at the closing market price and held until 
$6,12,18,24,30$ and 36 months following the listing date for the full sample of 36 IPOs. As mentioned earlier, of the 40 IPOs, only 36 companies that have a full 36 monthly returns in the sample will be included in the analysis.

The buy-and-hold returns, $B H R_{m T}$ for the market benchmarks, represented by the EWI and VWI for the Tadawul are:

$$
B H R_{m T}=\left[\prod_{t=1}^{T}\left(1+r_{m t}\right)\right]-1
$$

$r_{m t}$ is the corresponding monthly index level of SAS$E W I$ and SAS-VWI in event period t. The marketadjusted buy-and-hold abnormal returns for each share or company in the sample in event period $t$ are computed as:

$$
B_{H A R_{j t}}=\left[\prod_{t=1}^{T}\left(1+r_{j t}\right)\right]-\left[\prod_{t=1}^{T}\left(1+r_{m t}\right)-1\right]
$$

Where, $B H A R_{j t}$ is the buy-and-hold abnormal return of share $j$ in event period $t$. This allows the present study to measure the market-adjusted buy-and-hold abnormal returns earned by investors over the 6,12 , $18,24,30$ and 36 months following the listing date of Sharia Compliance IPO companies. The test-statistic for the market-adjusted monthly buy-and-hold abnormal returns, $\operatorname{BHAR}_{\left(t_{1}, t_{2}\right)}$ during the clustering period from $t_{1}$ to period $t_{2}$, is calculated as:

$t=\frac{\overline{B H A R}_{\left(t_{1}, t_{2}\right)}}{\sigma\left(B H A R_{t}\right) / \sqrt{T}}$

Where, $\overline{B H A R}_{\left(t_{1}, t_{2}\right)}$ is the market-adjusted monthly average buy-and-hold abnormal return from period $t_{1}$ to period $t_{2}$; and $\sigma\left(B H A R_{t}\right)$ is the standard deviation of market-adjusted monthly buy-and-hold abnormal return in event period $t$, and $T$ is the total number of Shariacompliant IPO companies in the sample.

\section{RESULTS AND FINDINGS}

\subsection{Composition of Sharia-Compliant IPO Companies}

Figure 1 shows the distribution of IPOs from year 2004 to 2017. Notably, IPO activity by Saudi Arabian listed companies began in the early Noughties in tandem with the development of the Saudi Arabian capital market. Out of 45 cases, $40 \%$ of the IPO announcements occurred during bear periods from 2007 to 2009. These listings reached their peak in the year 2008, with nine (9) new listings, and slightly declined after 2008 following the onset of the global financial crisis.

\subsection{Descriptive Statistic}

Table 1 presents the descriptive statistics of raw initial returns and market-adjusted initial returns for the sample of 40 Sharia-compliant IPO companies listed on the Saudi Arabian Stock Exchange (Tadawul) from January 2004 to August 2017. As mentioned earlier, five Sharia-compliant IPO companies were excluded from the analysis due to unavailability of data and exclusion of the REIT Fund industry sector. The raw initial returns to shareholders range from a low of $58.3 \%$ to a high of $965.6 \%$. By looking at initial returns for each company, this study finds that the minimum initial return was reported by Herfy Foods Services which was listed on $2^{\text {nd }}$ February 2010 . The offer price for this company was SAR51 and its closing price on the first day of listing dived to SAR21.29, yielding a negative initial return of $-58.3 \%$. On the other hand, the

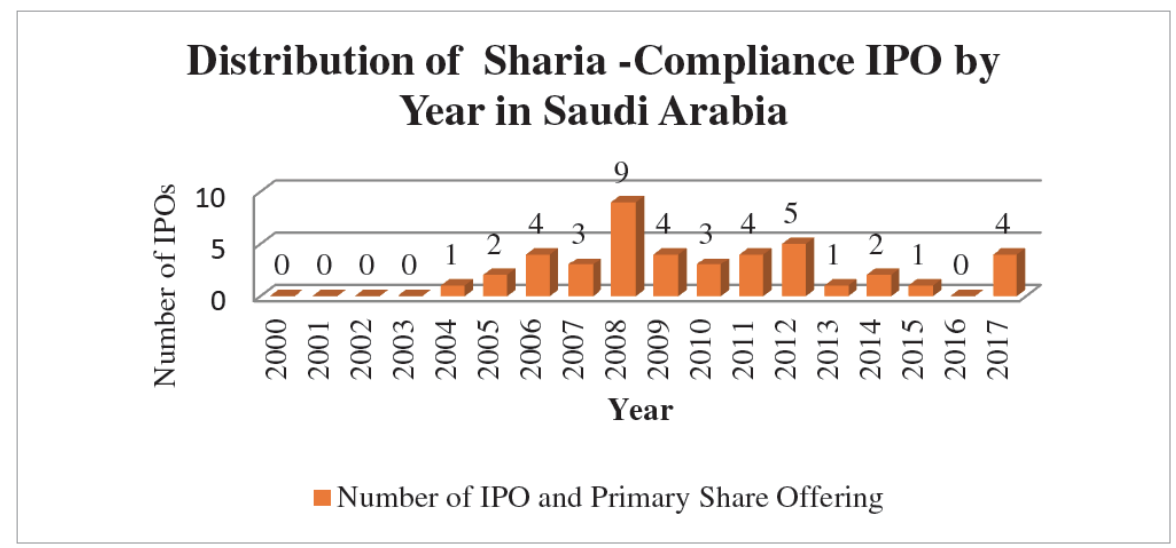

Figure 1: Distribution of Sharia-Compliant IPOs by Year.

Source: Bloomberg, 2017. 
Table 1: Raw and Market-Adjusted Initial Returns for 40 Sharia-Compliant IPOs Listed on the Saudi Arabian Stock Exchange from 2004-2017

\begin{tabular}{|c|c|c|}
\hline IPO & Raw Initial Returns & Market-Adjusted Returns \\
\hline \hline Mean & $79.6 \%^{\mathrm{a}}$ & $79.23 \%^{\mathrm{a}}$ \\
\hline Standard deviation & 1.995 & 1.991 \\
\hline Minimum & $-58.3 \%$ & -0.58471 \\
\hline Median & $15.7 \%^{\mathrm{b}}$ & $16.71 \%^{\mathrm{b}}$ \\
\hline Maximum & $965.6 \%$ & $963.9319 \%^{\circ}$ \\
\hline Skewness & 3.052 & 3.060 \\
\hline Kurtosis & 10.573 & 10.607 \\
\hline
\end{tabular}

Note:

${ }^{a}$ Significantly different from zero at the 0.05 level, using a two-tailed test. The parametric t-test is used for means and the Wilcoxon Signed-Rank test is used for median.

*The initial return is defined as the return from the offering price to the closing price on the first day of listing. The market-adjusted is defined as the initial raw returns minus the return on the Tadawul All-Shares Index (TASI) during the corresponding period.

maximum initial return of $965.6 \%$ was reported in year 2009 by a well-known company to date, namely Etihad Atheeb Telecommunication, which was listed on $21^{\text {st }}$ March 2009. Notably, the offer price for this company was SAR10 and its closing price on the first day of listing jumped to SAR106.56, generating a remarkably positive initial return of $965.6 \%$.

Interestingly, the analysis shows that there is abnormal return of $79.23 \%$ (statistically significant at $5 \%$ level; t-statistic of 2.52) to shareholders who purchased the Sharia-compliant IPO shares on the offering date and sell them on the first day of trading. This study contributes to the evidence that Shariacompliant IPOs on the Saudi Arabian stock market are underpricing. The findings generally sit alongside the evidence put forth by studies in developed and developing countries; as compiled by $\mathrm{T}$. Loughran et al. (1994) in their work which documented that the average initial returns for 52 countries between the periods of 1971 to 2014 is in the range of $3.3 \%$ to $239.8 \%$. While the initial returns of $79.23 \%$ in the present work is substantially high in comparison with an earlier study on Sharia-compliant IPOs in Malaysia which is $31.99 \%$ (Abdul Rahim \& Yong, 2010) it is still only one-half of the amount documented by Mayes and Alqahtani (2015) at $164.5 \%$ of average initial returns of Sharia-compliant IPOs in Saudi Arabia and even further from what is documented by $\mathrm{T}$. Loughran et al. (1994), for overall initial returns in the Saudi market of $239.8 \%$. This study can plausibly argue that the initial returns are significantly reduced, given the fact that the REIT industry is excluded from the final sample. The authors believed that omitting the REIT industry is very important, as the REIT industry operates within a highly regulated market in Saudi Arabia. As has been pointed out by Boulanouar and Alqahtani (2016) who studied the insurance industry in Saudi Arabia, all insurance companies are required to complete their listing requirements for the Saudi Stock Exchange prior to getting their license from the Saudi Arabian Monetary Agency (SAMA), the regulatory body of the insurance industry. In other countries, highly regulated sectors engender a high transparency level from companies, which reduces the occurrence of information asymmetry relating to IPO issuance and inadvertently reduces the level of underpricing (see Rahman \& Yung, 1999). Notably, this is not the case in Saudi Arabia as depicted by Boulanouar and Alqahtani (2016). They documented average initial returns of $455 \%$ for the Saudi Arabian insurance market, one of the highest levels of all time. Thus, eliminating REIT from the sample has clearly reduced the average initial returns as reported by the findings of this research. This leads to better understanding of the market behaviour in Saudi Arabia as it is not being overshadowed by a regulated industry and reduces the potential for embedding inefficient and imperfect market conditions in the calculation of average initial returns, which had been documented in earlier studies in Saudi Arabia; of interest is Mayes and Alqahtani (2015)'s which also examines the underpricing level of Sharia-compliant IPO companies in Saudi Arabia.

In addition, the level of underpricing in this study may also be explained by the market condition of the sample data used. Unlike earlier studies that are more concentrated during the 'hot market' period (see Ahmed S. Alanazi \& Al-Zoubi, 2015; Mayes \& Alqahtani, 2015), our study encompasses much longer period (2004 to 2017) where IPO activities experienced both pre-and post-financial crisis condition. Arguably, 
Table 2: Average Market-Adjusted Buy-and-Hold Returns for Sharia-Compliant IPO Companies

\begin{tabular}{|c|c|c|c|c|c|c|c|c|c|c|c|c|}
\hline \multicolumn{1}{|c|}{ Average Market-Adjusted Buy-and-Hold Returns for Sharia-compliant IPO Companies listed on the TadawuI } \\
\hline Market Indices & \multicolumn{10}{c|}{ SAS-EWI } \\
\hline \hline & \multicolumn{10}{|c|}{ Months After the Listing of Sharia Compliance IPO Companies } \\
\hline & 6 & 12 & 18 & 24 & 30 & 36 & 6 & 12 & 18 & 24 & 30 & 36 \\
\hline $\begin{array}{c}\text { Market-Adjusted } \\
\text { BHARs (\%) }\end{array}$ & 5.53 & 10.49 & 14.67 & 12.38 & 11.95 & 7.50 & 5.73 & 6.93 & 8.91 & 4.32 & 6.30 & 2.41 \\
\hline T-Stat & 1.24 & 1.53 & $1.69^{*}$ & 1.63 & 1.53 & 0.98 & 1.20 & 1.05 & 1.13 & 0.64 & 0.85 & 0.33 \\
\hline
\end{tabular}

Note: Average market-adjusted buy-and-hold abnormal returns for shares within a portfolio are calculated for periods of $6,12,18,24,30$ and 36 months following the listing of Sharia-compliant IPO companies on the Saudi Arabian Stock Exchange against the SAS-EWI and SAS-VWI benchmarks. SAS-EWI denotes the Saudi Arabian All Shares-Equal Weight Index. On the other hand, SAS-VWI denotes the Saudi Arabian All-Shares Value Weight Index. An asterisk (*) indicates a statistical significance at the $10 \%$ level, using a two-tailed test.

by including the IPO performance during the bear market condition (post-2008) moderates the extreme underpricing level as observed in earlier findings for the Saudi market as documented by Mayes and Alqahtani (2015) and Ahmed S. Alanazi and Al-Zoubi (2015).

\subsection{Long Run Share Price Performance}

Table 2 presents the percentage average marketadjusted buy-and-hold returns for Sharia-compliant IPO companies for the first 6 months, and for months 12 , $18,24,30$ and 36 after the listing date for the 36 IPOs occurring between the year 2000 and 2014. The share price data was last collected on $31^{\text {st }}$ August 2017. Hence, this research finds that the number of Shariacompliant IPO companies having a full 36 months of return is much less than the total number of IPOs reported in Saudi Arabia. The post long-run performance of Sharia-compliant IPO companies were analysed separately using two indices created by the authors; equal weight index (EWI) and value weight index (VWI).

The results of the t-test for the stock portfolios from the EWI index against market-adjusted buy-and-hold abnormal return was 1.24 (not significant at $p=0.10$ ), and BHAR was $5.53 \%$ for the sixth-month period; 1.53 (not significant at $p=0.10$ ), and BHAR was $10.49 \%$ for the twelve-month period; 1.69 (significant at $p=0.10$ ), and BHAR was $14.67 \%$ for an eighteen-month period; 1.63 (not significant at $p=0.10$ ), and BHAR was $12.38 \%$ for a twenty-four-month period; 1.53 (not significant at $p=0.1$ ), and BHAR was $11.95 \%$ for a thirty-month period; and 0.98 (not significant at $p=0.1$ ), and BHAR was $7.50 \%$ for a thirty-six-month period. These results reflected that investors gained positive and significant abnormal returns only after an eighteen-month period; implying that abnormal return was reassured at the highest though it requires a longer period of holding the portfolios.
The t-test results for the market-adjusted buy-andhold abnormal return against the VWI index was 1.20 (not significant at $p=0.10$ ), and BHAR was $5.73 \%$ for the six-month period; 1.05 (not significant at $p=0.10$ ), and BHAR was $6.93 \%$ for the twelve-month period; 1.13 (not significant at $p=0.10$ ), and BHAR was $8.91 \%$ for the eighteen-month period; 0.64 (not significant at $p$ $=0.10$ ), and BHAR was $4.32 \%$ for the twenty-fourmonth period; 0.85 (not significant at $p=0.10$ ), and BHAR was $6.30 \%$ for the thirty-month period; and 0.33 (not significant at $p=0.10$ ), and BHAR was $2.41 \%$ for the thirty-six-month period. Despite the insignificant values, this study finds that IPO companies still outperformed the SAS-VWI. Further, the results indicate that the market-adjusted buy-and-hold abnormal returns are much lower than those reported in the equal-weight index.

\section{CONCLUSION}

Overall, our findings suggest that investors who purchase Sharia-compliant IPO shares at the offering date and sell them on the first day of trading gain high positive initial returns, while those investors who hold shares for a longer period, up to 36 months following the listing date of IPO companies do not gain as much. Further, the findings of the present study would benefit foreign investors and market regulators who are trying to understand the market behaviour in an emerging market. The very high level of underpricing on the Saudi Stock Exchange reported in earlier studies (for example, T. Loughran et al., 1994; Mayes \& Alqahtani, 2015) may have created hesitancy among foreign investors to invest in this region. Foreign institutions may perceive this as a deliberate underpricing tactic and attribute this to the market inefficiency and information asymmetry condition of a typical emerging market. Since this study has shown that the level of underpricing has reduced, it gives an indication that the 
market reform initiatives by the Capital Market Authority over the years are effective in creating stable, predictable and hopefully more transparent market exchange, which, inadvertently, attracts future investment. Lastly, as there is no international evidence on the long-run share performance of Sharia-compliant IPO companies, the findings on the long-run overperformance adds to the body of knowledge in the IPO literature. However, further research examining many aspects of Sharia investments is required as it is very much an understudied area both in Saudi Arabia and internationally.

\section{ACKNOWLEDGEMENT}

This work was supported by the Seed Research Project; Prince Sultan University; Saudi Arabia [grant number IBRP-CBA-2018-10-3].

\section{REFERENCES}

Abdul Rahim, R., \& Yong, O. (2010). Initial returns of Malaysian IPOs and Shari'a-compliant status. Journal of Islamic Accounting and Business Research, 1(1), 60-74. https://doi.org/10.1108/17590811011033415

Ahmad-Zaluki, N. A., Campbell, K., \& Goodacre, A. (2007). The Long Run Share Price Performance of Malaysian Initial Public Offerings (IPOs). Journal of Business Finance \& Accounting, 34(1\&2), 78-110. https://doi.org/10.1111/j.1468-5957.2006.00655.x

Al-Hassan, A., Delgado, F., \& Omran, M. (2010). The under-pricing of IPOs in the Gulf Cooperation Council countries. Research in International Business and Finance, 24(3), 344-360. https://doi.org/10.1016/j.ribaf.2010.03.002

Alanazi, A. S., \& Al-Zoubi, H. A. (2015). Extreme IPO underpricing and the legal environment in wealthy emerging economies. Journal of Multinational Financial Management, 31, 83-103. https://doi.org/10.1016/j.mulfin.2015.05.004

Alanazi, A. S., Liu, B., \& Forster, J. (2011). The financial performance of Saudi Arabian IPOs. International Journal of Islamic and Middle Eastern Finance and Management, 4(2), 146-157. https://doi.org/10.1108/17538391111144533

Allen, F., \& Faulhaber, G. (1989). Signaling by under-pricing the IPO market. Journal of Financial Economics, 23, 303-323. https://doi.org/10.1016/0304-405X(89)90060-3

Alqahtani, F. (2011). Long-run market performance of initial public offerings in Saudi Arabia: Does Shariah compliance matter. https://doi.org/10.2139/ssrn.2214841

Alqahtani, F., \& Boulanouar, Z. (2017). Long-run market performance of initial public offerings in Saudi Arabia: Does Shariacompliant status matter. Corporate Ownership \& Control, 14(2-3), 293-298. https://doi.org/10.22495/cocv14i3c2art3

Álvarez, S., \& González, V. (2005). Signalling and the long-run performance of Spanish initial public offerings (IPOs). Journal of Business Finance \& Accounting, 32(1-2), 325-350. https://doi.org/10.1111/j.0306-686X.2005.00596.x

Banu Durukan, M. (2002). The relationship between IPO returns and factors influencing IPO performance: case of Istanbul Stock Exchange. Managerial Finance, 28(2), 18-38. https://doi.org/10.1108/03074350210767672
Barber, B., \& Lyon, J. (1997). Detecting long-run abnormal stock returns: The empirical power and specification of test statistics. Journal of Financial Economics, 43(3), 341-372. https://doi.org/10.1016/S0304-405X(96)00890-2

Boulanouar, Z., \& Alqahtani, F. (2016). IPO underpricing in the insurance industry and the effect of Sharia compliance: Evidence from Saudi Arabian market. International Journal of Islamic and Middle Eastern Finance and Management, 9(3), 314-332. https://doi.org/10.1108/IMEFM-12-2014-0118

Capital, A. R. (2017). Sharia Guidelines for Trading and Investment in Stocks. Retrieved from www.alrajhicapital.com/en/Pages/shariahguide.aspx

Espenlaub, S., Gregory, A., \& Tonks, I. (2000). Reassessing the long-term underperformance of UK Initial Public Offerings. European Financial Management, 6(3), 319-342. https://doi.org/10.1111/1468-036X.00127

Fama, E. (1998). Market efficiency, long-term returns, and behavioral finance. Journal of Financial Economics, 49, 283-306. https://doi.org/10.1016/S0304-405X(98)00026-9

Gompers, P., \& Lerner, J. (2003). The really long-run performance of initial public offerings: the Pre-Nasdaq evidence. The Journal of Finance, 58(4), 1355-1392. https://doi.org/10.1111/1540-6261.00570

Keloharju, M. (1993). The winner's curse, legal liability, and the longrun price performance of initial public offerings in Finland. Journal of Financial Economics, 34(2), 251-277. https://doi.org/10.1016/0304-405X(93)90020-C

Khurshed, A., Mudambi, R., \& Goergen, M. (1999). On the long-run performance of IPOs. Working paper. University of Reading and UMIST.

Lee, P., Taylor, S., \& Walter, T. (1996a). Australian IPO pricing in the short and long-run. Journal of Banking \& Finance, 20(7), 1189-1210. https://doi.org/10.1016/0378-4266(95)00053-4

Lee, P., Taylor, S., \& Walter, T. (1996b). Expected and realised returns for Singaporean IPOs: Initial and long-run analysis. Pacific-Basin Finance Journal, 4(2-3), 153- 180. https://doi.org/10.1016/0927-538X(96)00009-1

Levis, M. (1993). The long-run performance of initial public offerings: the UK experience 1980-1988. Financial Management, 22(1) https://doi.org/10.2307/3665963

Loughran, T. (1993). NYSE vs NASDAQ returns: Market microstructure or the poor performance of initial public offerings? Journal of Financial Economics, 33(2). https://doi.org/10.1016/0304-405X(93)90006-W

Loughran, T., \& Ritter, J. (1995). The new issues puzzle. The Journal of Finance, 50(1), 23-51. https://doi.org/10.1111/j.1540-6261.1995.tb05166.x

Loughran, T., Ritter, J., \& Rydqvist, K. (1994). Initial public offerings: International insights. Pacific-Basin Finance Journal, 3(1), 139-140. https://doi.org/10.1016/0927-538X(95)99082-D

Lyon, J., Barber, B., \& Tsai, C. (1999). Improved methods for tests of long-run abnormal stock returns. The Journal of Finance, 54(1), 165-201. https://doi.org/10.1111/0022-1082.00101

List of Shariah-Compliant Securities by the Shariah Advisory Council of the Securities Commission Malaysia, (2017).

Mayes, D., \& Alqahtani, F. (2015). Underpricing of IPOs in Saudi Arabia and Sharia compliance. Journal of Islamic Accounting and Business Research, 6(2), 189-207. https://doi.org/10.1108/JIABR-12-2013-0042

Rahman, H., \& Yung, K. (1999). Insurance IPOs - a test of underpricing theories. Journal of Insurance Issues, 1(22), 61-77.

Ritter, J. (1984). The "Hot Issue" Market of 1980. The Journal of Business, 57(2), 215-240. https://doi.org/10.1086/296260 
Ritter, J. (1991). The long-run performance of initial public offerings. The Journal of Finance, 46(1). https://doi.org/10.1111/j.1540-6261.1991.tb03743.x

Rock, K. (1986). Why new issues are underpriced. Journal of Financial Economics, 15(1-2), 187-212. https://doi.org/10.1016/0304-405X(86)90054-1
Stehle, R., Ehrhardt, O., \& Przyborowsky, R. (2000). Long-run stock performance of German initial public offerings and seasoned equity issues. European Financial Management, 6(2), 173196.

https://doi.org/10.1111/1468-036X.00119

Tully, S. (1999). Will the web eat Wall Street? In (pp. 98-102). United States: Time Life.

Received on 18-07-2019

Accepted on 01-08-2019

Published on 24-09-2019

DOI: https://doi.org/10.6000/1929-7092.2019.08.61

(c) 2019 Kamaludin and Zakaria; Licensee Lifescience Global.

This is an open access article licensed under the terms of the Creative Commons Attribution Non-Commercial License (http://creativecommons.org/licenses/by-nc/3.0/) which permits unrestricted, non-commercial use, distribution and reproduction in any medium, provided the work is properly cited. 